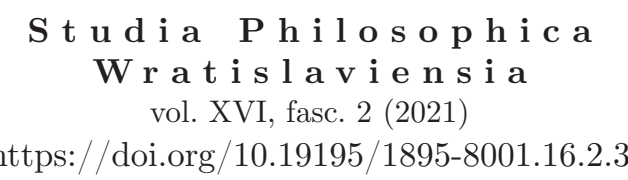

\author{
LESZEK KLESZCZ \\ ORCID: 0000-0002-4570-6854 \\ Uniwersytet Wrocławski \\ KRZYSZTOF SZTALT \\ ORCID: 0000-0003-4549-8263 \\ Uniwersytet Wrocławski
}

\title{
Kultura i mit — iluzje demitologizacji
}

\section{Culture and myth — the illusions of demythologization}

\begin{abstract}
One of the most fundamental existential experiences is the "indifference of the world". Faced with the awareness of the insignificance of human fate, the lack of meaning, the indifference of the world, man creates various strategies of depotentialising reality. One of them is "story-telling", working on a myth. Nietzsche also believed that "life needs a protective atmosphere woven from illusions, dreams, delusions", so he tried to create a myth to fill the void left by the "death of God". He began with Wagner's "aesthetic myth" and went on to create a "myth of the aestheticisation of existence". His next attempts to give meaning to human life were the story of the Übermensch and the revitalization of the myth of eternal return. Another myth which can be found at the core of Nietzsche's philosophy is "the myth of the myth-maker".
\end{abstract}

Keywords: Culture, myth, Nietzsche, Wagner, Blumenberg

Jednym z najbardziej fundamentalnych doświadczeń egzystencjalnych jest „fenomen obojętności świata"1. Uciekamy przed tym uczuciem, a próby jego przezwyciężenia stanowią jeden z zasadniczych elementów ludzkiej kultury. Wciąż podejmujemy próby jakiegoś zakorzenienia się w świecie, odnalezienia w nim ładu,

\footnotetext{
${ }^{1}$ L. Kołakowski, Obecność mitu, Wrocław 1994, s. 79.
} 
porządku, własnego miejsca. Pragniemy „oswoić świat”, by wyzwolić się spod władzy czasu i przemijania, tęsknimy za „rajem”. W istocie na całą kulturę możemy patrzeć jak na wielki „magazyn środków przeciwbólowych”. Należy do nich zarówno religia, nauka, sztuka, jak i pogoń za rozkoszą, zanurzenie w codzienności i koncentracja na „tu i teraz”.

Być może początkiem filozofii, a więc namysłu nad światem i życiem — jak zauważył Schopenhauer — nie było zdziwienie, ale przerażenie. Człowiek, pragnąc uczynić swą egzystencję bardziej znośną, opracowuje różne strategie przetrwania w niesprzyjających warunkach, buduje sobie nisze, w których może się schronić. Jedną z najstarszych a zarazem najbardziej skutecznych ,strategii oswajania rzeczywistości” jest „snucie opowieści”, tworzenie „wielkich narracji”, wśród których szczególne miejsce zajmują mity.

W myśleniu mitycznym wyraża się podstawowe doświadczenie egzystencjalne, którym jest pragnienie nadania sensu własnemu życiu, wyzwolenia spod „władzy czasu”, poprzez jego „unieruchomienie”. Myślenie mityczne według Leszka Kołakowskiego ,jest zawsze wyzwaniem rzuconym przemijaniu, jest zatrzymaniem upływu czasu, jest osobliwym dzianiem się", które zawiesza realne następstwo chwil i daje się odtworzyć w wersji zawsze tak samo oryginalnej"2.

Lecz czym właściwie jest „mit”? Potocznie kojarzy się z „fikcją”, ,iluzją”, jest synonimem „baśni”. Mircea Eliade uważa, że jest wręcz przeciwnie — mit oznacza dla niego „historię prawdziwą”, „historię, która ma niezwykłą wartość, ponieważ jest święta, brzemienna w znaczenia i pouczająca"3. Mit:

opisuje wydarzenie, które miało miejsce w okresie wyjściowym, legendarnym czasie 'początków'. Inaczej mówiąc: mit opowiada, w jaki sposób, za sprawą dokonań Istot Nadnaturalnych, zaistniała nasza rzeczywistość, bądź rzeczywistość globalna - Kosmos, bądź tylko pewien jej fragment: wyspa, gatunek roślin, ludzkie zachowanie, instytucja. Tak więc zawsze jest to opowieść o 'stworzeniu', relacja o tym, jak coś powstało, zaczęło być. Mit mówi tylko o tym, co wydarzyło się faktycznie, o tym, co przejawiło się w sposób wyraźny. Bohaterowie mitów to Istoty Nadnaturalne. Znane są one przede wszystkim za sprawą tego, co uczyniły w magicznym czasie 'początków'. Mity ujawniają ich twórczą działalność i pouczają o świętości (lub po prostu o 'nadnaturalności') tego, co jest ich rezultatem. W sumie, mity opisują różnorodne i czasem dramatyczne wtargnięcia sfery sacrum (lub 'nad-naturalności') w obręb świata. To na tym wtargnięciu ufundowany jest świat i właśnie za jego sprawą jest on taki, jakim go dziś widzimy ${ }^{4}$.

Mity, opowiadając o czynach tych wielkich istot, pełnią funkcję wzorcotwórczą, stają się modelem, który ludzie powinni naśladować.

Istnieje wyraźna różnica między światem mitycznym a światem zsekularyzowanym. Człowiek mityczny żyje w czasie świętym, a pomiędzy czasem początków a współczesnością istnieje stała więź, bezpośredni związek. Czas święty ma charakter kolisty. Natomiast człowiek świecki żyje w czasie linearnym, w historii, gdzie poszczególne wydarzenia wiąże ze sobą tylko rozluźniający się w czasie związek

${ }^{2}$ L. Kołakowski, Mircea Eliade: religia jako paraliż czasu, [w:] M. Eliade, Traktat o historii religii, tłum. J. Wierusz Kowalski, Warszawa 1993, s. IV; L. Kleszcz, Eliade - życie i mit, [w:] Studia mitoznawcze: filozoficzne i socjologiczne aspekty mitu, I. Błocian, E. Kwiatkowska (red.), Toruń 2010, s. $201-214$.

${ }^{3}$ M. Eliade, Aspekty mitu, tłum. P. Mrówczyński, Warszawa 1998, s. 7.

${ }^{4}$ Ibidem, s. 11. 
przyczynowo-skutkowy. Przeszłość nie ma już charakteru normatywnego, nie stanowi żadnego wzorca, bo w żaden sposób nie może się już powtórzyć. Nieodwracalność jest jedną z zasadniczych cech świata historycznego. Eliade podkreślał, że tradycyjne mity w świecie współczesnym nie zniknęły, one wciąż trwają, choć w zdeformowanej postaci. Możemy je dostrzec w sztuce, kulturze popularnej czy też niektórych zachowaniach w życiu codziennym. Myślenie mityczne jest obecne zarówno w próbach ożywienia mitu, jak i dążeniach do demitologizacji kultury. Filozofia jest dla Eliadego kontynuatorką mitu w jego funkcji umniejszania lęku, jednak sam mit — jak podkreśla stanowczo — stanowi już „wysokokaratową próbę logosu". Relacja między mitem a logosem nie jest tak prosta, jak to sobie tradycyjnie przedstawiano. Wprawdzie mit bywa wypierany lub zastępowany przez logos, ale w obliczu nieuchronnego, a przynajmniej wciąż się powtarzającego, rozczarowania osiągnięciami logosu, następuje ponowna mityzacja rzeczywistości. Dlatego w dziejach filozofii „mamy raczej do czynienia z ciągła reinterpretacją opowieści dziedziczonych lub — gdy tracą one siłę oddziaływania lub zdolność dystansowania wobec nowych źródeł lęku — z tworzeniem nowych mitów"5.

Hans Blumenberg dowodzi, że antyteza mitu i logosu jest późnym i nieprawdziwym wynalazkiem, gdyż już u podstaw oświecenia, rozumianego jako dążenie do przezwyciężeniu mitu przez rozum, leży myślenie mityczne, gdyż wypływa ono z pragnienia przezwyciężenia obcości świata, a więc jest to ten sam archetypiczny motyw, z którego zrodził się mit. Dlatego według Blumenberga historię kultury należałoby postrzegać nie tyle przez schemat tradycyjnego przechodzenia „od mitu do logosu", ile raczej jako swoistą dialektykę mitu i logosu. Zewnętrznie przybiera ona formę wypierania mitu przez logos, lecz po jakimś czasie okazuje się, że ów logos był tylko innac postacią mitu. Ten splot mitu i logosu leży również u podstaw współczesności. Dla zrozumienia współczesności kluczowe znaczenie zdają się posiadać konsekwencje narodzin nowożytnej nauki, które spotęgowały odczucie „absolutyzmu rzeczywistości”6. Bardzo ważnym elementem absolutyzmu rzeczywistości zrodzonym przez naukę nowożytną było rozwarcie nożyc czasoprzestrzennych. Rozejście się czasu istnienia świata i długości ludzkiego życia wydobywa znikomość, a właściwie przekreśla wartość ludzkiego życia, które w porównaniu z czasem trwania wszechświata jest tylko chwilką, mgnieniem, nic nieznaczącym epizodem. Podobnie jest z nieskończonymi przestrzeniami, które pokazują nikłość i peryferyjność naszego świata. Dominuje przekonanie, że nauka umożliwia człowiekowi zadomowienie się we wszechmocnej naturze. Blumenberg uważa, że jest wręcz odwrotnie, gdyż efektem rozwoju nowożytnej nauki stało się „odczarowanie świata” i kolejne „rany zadane ludzkiej próżności”. Zarazem wskazuje, że w wielkich koncepcjach naukowych zawarta jest pewnego rodzaju dwuznaczność, na przykład teoria kopernikańska z jednej strony była triumfem ludzkiego umysłu, ale z drugiej oznaczała degradację człowieka i utratę centralnego miejsca w świecie. Ta

\footnotetext{
5 Ibidem, s. 12.

${ }^{6}$ Dla Blumenberga pojęcie „absolutyzmu rzeczywistości” oznaczało, ,że nad warunkami swojej egzystencji człowiek właściwie nie panował, a co ważniejsze — nie myślał nawet, że nad nimi panuje"; idem, Praca nad mitem, tłum. K. Najdek, M. Herer, Z. Zwoliński, Warszawa 2009, s. 3.
} 
dwuznaczność nauki jest stałym elementem świata nowożytnego. Dla jednych, na przykład Bacona czy Kartezjusza, rozwój poznania, poszerzanie granic, obszarów, do których wgląd zyskuje ludzki umysł, jest potwierdzeniem ludzkiej mocy, czyni go „panem przyrody”, a może nawet „panem życia”, u innych zaś, na przykład Pascala, „rozwieranie nożyc czasoprzestrzennych” budzi przerażenie.

Odbiciem tych dwóch postaw był spór romantyzmu z oświeceniem o miejsce i rolę mitu w kulturze. Z oświeceniowego punktu widzenia mit jest przejawem irracjonalizmu i niedojrzałości, a przezwyciężający go logos ustanawia miejsce dla rozumu i krytyki. Z kolei krytycy oświecenia wskazywali na naiwność takiego myślenia, gdyż świat oświeceniowy jest światem odczarowanym, w którym nie może znaleźć zaspokojenia ludzka potrzeba sensu. Efektem „oświecenia oświecenia” były romantyczne próby stworzenia ,nowej mitologii” i ponownego ,zaczarowania świata"7. Fryderyk Schlegel za kluczowe dla powstania ruchu romantycznego uznał teorię wiedzy Fichtego, rewolucję francuską oraz Wilhelma Meistra Goethego. Jednak tym zjawiskiem, które miało decydujące znaczenie dla powstania romantyzmu, było doświadczenie ,śmierci Boga”. Jego filozoficznych korzeni można szukać zarówno w oświeceniowej krytyce religii, jak w Kantowskiej krytyce metafizyki, o której światopoglądowych konsekwencjach dramatycznie pisał Kleist:

Zdaje się, że zostanę jedną z ofiar szaleństwa, których tyle ma na swoim sumieniu filozofia Kanta. Przejmuje mnie wstrętem to społeczeństwo, a jednak nie mogę się uwolnić od jego więzów. Myśl, że my tu na tym padole nic a nic nie wiemy o prawdzie, że to, co tu zwiemy prawdą, po śmierci zupełnie inaczej się mieni, a zatem i nasze dążenie do tego, by zdobyć na własność coś, co by nam mogło towarzyszyć aż po sam grób, daremne jest i bezowocne, myśl ta wstrząsnęła całym mym jestestwem. Runął mój jedyny, najwyższy cel, innego nie mam

Podobnie odczuwał to Heine, nazywając filozofię Kanta mieczem, którym ścięto głowę teizmowi ${ }^{9}$.

Śmierć Boga oznaczała, że dotychczasowa podstawa życia duchowego, społecznego przestała być wiarygodna, a kultura, życie, sztuka potrzebują nowego oparcia, duchowego centrum organizującego całą ludzką aktywność. Duchową pustkę, którą romantycy z całą siłą odczuwali, miała wypełnić idea „nowej mitologii”:

Nowa mitologia - pisał Schlegel — w przeciwieństwie do starej musi wykształcić się z najprzepastniejszych głębi ducha; musi to być najkunsztowniejsze ze wszystkich dzieł sztuki, winno bowiem ogarnąć wszystkie inne, być nowym łożyskiem i naczyniem dla dawnego, wiecznego praźródła poezji — samemu będąc poematem nieskończonym, kryjącym w sobie zalążki wszystkich innych ${ }^{10}$.

Romantycy dążyli do ponownego ,zaczarowania świata” poprzez dokonanie rewolucji intelektualnej, estetycznej i obyczajowej. Ważnym elementem tej rewolucji było „uwolnienie wyobraźni”, wydobycie myślenia z utartych kolein, wywrócenie

${ }^{7}$ E. Mieletinski podkreśla znaczenie filozofii mitu Schellinga, ale ważną rolę odegrali także bracia Schleglowie, Novalis czy Schleiermacher, por. E. Mieletinski, Poetyka mitu, tłum. J. Dancygier, Warszawa 1981, s. 27-31; por. także L. Kleszcz, Przełom hermeneutyczny w filozofii niemieckiej, Toruń 2007, s. 299-304.

${ }^{8}$ H. von Kleist, Listy, tłum. W. Markowska, Warszawa 1983, s. 330-331.

${ }^{9}$ H. Heine, Z dziejów religii i filozofii w Niemczech, tłum. T. Zatorski, Kraków 1997, s. 108.

${ }^{10}$ F. Schlegel, Rozmowa o poezji, [w:] Pisma teoretyczne niemieckich romantyków, T. Namowicz (red.), Wrocław-Warszawa-Kraków 2000, s. 151. 
dominujących schematów myślenia i wartościowania. Stąd brało się romantyczne „pisanie obiema rękami” ${ }^{11}$. Celem romantyków było pokazanie, że wszystko, do czego przywykliśmy, co uznajemy za oczywiste w myśleniu, wartościowaniu czy zachowaniu, jest tylko wynikiem pewnej konwencji, schematu, rytuału. Dlatego świat trzeba ,zromantyzować”:

W ten sposób — pisał Novalis — odnajdziemy pierwotny sens. Romantyzowanie to jakościowe potęgowanie. W działaniu tym niższe 'ja' utożsamia się z lepszym 'ja'. Tak jak my sami jesteśmy takim jakościowym spotęgowaniem. Działanie to jest jeszcze całkowicie nie znane. Nadając rzeczom pospolitym wyższy sens, zwykłym — tajemniczy wygląd, znanym — godność rzeczy nieznanych, skończonym - pozór nieskończoności, romantyzuję je. Odwrotnie przebiega to działanie w stosunku do rzeczy wyższych, nieznanych, mistycznych, nieskończonych, które przez połączenie to ulegają logarytmizacji. Otrzymują one znany wyraz. Filozofia romantyczna. Lingua romana. Wzajemne podniesienie i poniżenie ${ }^{12}$.

Nowa mitologia, będąca tożsama z poezją, miała umożliwiać nowy ogląd rzeczywistości. Drogą wiodącą ku niej było mieszanie gatunków, zderzanie przeciwieństw, przemienność form, nieustanne zmiany perspektyw, nastrojów, przechodzenie od entuzjazmu do ironii i odwrotnie. Idea nowej mitologii była wezwaniem do powszechnego odmłodzenia, do duchowej rewolucji.

Schlegel rozszerzył pojęcie mitologii, wskazując na jej wszechobecność. Podkreślał, że nie ma myślenia czy poznania bez jakiejś mitologii. Nawet najbardziej, jak pisał, ,realistyczny realizm” ma swoje poetyckie praźródła. Również u podstaw nauki, nawet ,arcymaterialnej” fizyki, tkwią pewne symboliczne obrazy, wizje światopoglądowe, czy też, jak później powie H. Blumenberg, pewne metafory absolut$n \mathrm{e}^{13}$. Romantycy odrzucali dualizm filozofii i sztuki, nie uznawali ich za dwie różne formy aktywności, lecz dążyli do połączenia filozofii i sztuki, by dzięki temu dokonała się „poetyzacja rzeczywistości”. Romantyczna rewolucja estetyczna sprawiła, że w sztuce punkt ciężkości przesunął się z zawartości dzieła na samego twórcę i subiektywne uwarunkowania jego twórczości. Dzieło artysty było wytworem jego wolnej wyobraźni, płynąc z jego mocy twórczej. Sztuka według romantyków nie naśladuje, ale tworzy własne, iluzyjne światy. Schlegel oczekiwał, że „refleksja filozoficzna nad aktem twórczym dokona się w formie literackiej, bowiem poeta winien być jednocześnie filozofem"14. Romantyzm próbował dokonać „estetyzacji życia”, to znaczy narzucenia rzeczywistości modelu estetycznego, poddania wszystkiego ocenie według kryteriów podobnych do tych, jakie obowiązują w sztuce.

Kontynuatorem idei romantycznych był Ryszard Wagner, który również pragnął dokonać remitologizacji kultury ${ }^{15}$. Marzył o sztuce, która zastąpi religię, któ-

${ }^{11}$ L. Kleszcz, Przełom hermeneutyczny w filozofii niemieckiej, s. 300-301.

12 Novalis, Poetycyzmy, [w:] idem, Uczniowie z Sais, tłum. J. Prokopiuk, Warszawa 1984, s. 202.

${ }^{13}$ L. Kleszcz, Przełom hermeneutyczny $w$ filozofii niemieckiej, s. 302.

14 T. Namowicz, Wstęp, [w:] Pisma teoretyczne niemieckich romantyków, s. LV.

15 Jak pisze E. Mieletinski: ,Tradycje romantyczne zachowały się w Niemczech przez cały wiek XIX $\mathrm{w}$ formie utajonej [...], toteż wczesne przejawy uświadomienia sobie kryzysu mieszczańskiej kultury Zachodu spowodowały tu pewnego rodzaju galwanizację apologetyki mitu na tej nowej — tragicznie kryzysowej — podstawie, w dodatku początkowo nie w sferze naukowej, lecz artystyczno-filozoficznej. Mamy tu na myśli przede wszystkim Wagnera [...] i Nietzschego, pozostających pod silnym wpływem Schopenhauera", idem, Poetyka mitu, s. 31. 
ra nada ludzkiemu życiu nowy sens. Wierzył, a przynajmniej głosił takie idee, że prawdziwa sztuka ponownie odrodzi się w przyszłości. Wagnerowska ,sztuka przyszłości” miała być „wytworem współpracy architekta, malarza, mima, poety i muzyka, którzy porzucą swą egoistyczną indywidualność i pracować będą razem dla wspólnego celu"16. Sztuka miała przypominać człowiekowi o prawdziwym celu jego istnienia, którym jest rozwój ludzkiej kreatywności. Jak pisał Wagner: „najwyższym celem człowieka jest cel artystyczny”17. Sztuka powinna pełnić funkcję podobną do greckich misteriów, kontakt z nią miał oczyszczać i wewnętrznie przemieniać. Wagner uważał, że w sytuacji obumierania religii, przybierania przez nią coraz bardziej „,sztucznych" form, ,sztuka ma prawo ratować istotę religii”"18. Nietzschego łączyło z Wagnerem poczucie głębokiej duchowej wspólnoty, podobnie diagnozował on stan kultury, podobną drogą zmierzał ku jej odrodzeniu. Obaj dostrzegali konieczność stworzenia „nowego mitu”, choć każdy wypełnił go inną treścią. Nietzsche uważał, że kultura znajduje się w stanie kryzysu, jednocześnie wierzył, że moment upadku może stać się momentem narodzin nowej kultury. W okresie pisania Narodzin tragedii Nietzsche był pod wrażeniem Wagnerowskiej „nowej mitologii”, przejął jego przekonanie, że życie potrzebuje „ochronnej atmosfery utkanej z iluzji, snów, złudzeń". Tę funkcję pełnią mity, dlatego Nietzsche propagował „mitotwórczą siłę dzieł Wagnera”, gdyż był przekonany, iż bez „mitu kultura traci swą zdrową, naturalną siłę twórczą. Dopiero wyznaczony mitami horyzont zamyka cały świat kultury w jednośc" 19 . W Narodzinach tragedii mit jest określany jako ,skondensowany obraz świata”, wprowadzający pewien porządek i sens w pustkę istnienia: „Mit i mitologizacja jest obrazowym nadawaniem sensu czemuś, co pozbawione jest sensu”, „Mity są to wartości potrzebne do odbudowania autentycznych więzi w społeczeństwie. Mity odpowiadają więc na wielkie milczenie przyrody i na erozję sensu w społeczeństwie"20.

Nietzsche, podobnie jak i Wagner, próbował ożywić mit. Wagner próbował dokonać mitologizacji sztuki, która miała zająć miejsce religii. Nietzsche początkowo był pod jego wpływem, później nabrał dystansu do Wagnerowskich idei. Dlatego, nawet jeśli nie potrafił dostrzec w świecie jakiegoś głębszego sensu i uważał, że znajduje on usprawiedliwienie tylko jako fenomen estetyczny, nawet jeśli doceniał miejsce i rolę muzyki w życiu, to jednak uświadomił sobie, że „sztuka nie zbawia" i dlatego postanowił szukać własnej drogi nadania sensu ludzkiej egzystencji. Punktem wyjścia filozofii Nietzschego było — jak już wspomniałem — przekonanie o kryzysie kultury europejskiej ${ }^{21}$. Jego istotę, najtrafniej chyba, ujął Nietzsche, mówiąc, iż „Bóg umarł”, nazywając tak proces, który toczył się od dawna, wszak już Hegel w zakończeniu Glauben und Wissen, tekście pochodzącym z 1802 roku,

${ }^{16}$ Pisma teoretyczne niemieckich romantyków, s. 73.

17 R. Safranski, Nietzsche. Biografia myśli, tłum. D. Stroińska, Warszawa 2003, s. 95; L. Kleszcz, Między miłościa a nienawiścia, czyli o dziwnej przyjaźni Nietzschego, [w:] Nietzsche - muzyka i język, A. Gemel, J. Wroński (red.), Łódź 2016, s. 137-145.

18 R. Safranski, Nietzsche, s. 99.

19 Ibidem, s. 89.

${ }^{20}$ R. Safranski, Nietzsche, s. 89-91.

${ }^{21}$ L. Kleszcz, Przełom hermeneutyczny w filozofii niemieckiej, s. 380-382. 
nazywa „uczucie, na którym polega religia ostatnich czasów — uczuciem: sam Bóg nie żyje"22. „Śmierć Boga" to (w sensie filozoficznym, a więc wychodzacym poza związki z tradycją chrześcijańską) określenie oznaczające wyczerpywanie się żywotności tradycji platońskiej. Trwający przez wiele stuleci eksperyment myślowy, projekt świata jako „wielkiego łańcucha bytu” dobiegł końca, a „Platoński schemat wszechświata odwrócony został do góry nogami" 23 . W miejsce pełnego, niezmiennego łańcucha bytu i rozumu pojawiły się czas, stawanie i przypadek. „Uczasowienie” Boga, świata i człowieka zaowocowało świadomością względności wszelkich prawd, wszelkiego poznania. Nawet sama racjonalność, pojmowana jako kompletna i pozbawiona wszelkiej arbitralności, stała się rodzajem irracjonalności. Nastąpiło przejście od świata jako „wielkiego łańcucha bytu” do świata „konkretnego istnienia" 24 .

Centralne miejsce $\mathrm{w}$ filozofii Nietzschego zajmuje problem nihilizmu. Jest to pojęcie wieloznaczne. Nietzsche wyróżnia nihilizm psychologiczny, zupełny, niezupełny, radykalny, bierny, aktywny, pesymistyczny i nihilizm płynący z mocy. Najważniejsze wydają się dwa określenia: po pierwsze, nihilizm jako stan kultury, w którym „,brak celu; brak odpowiedzi na pytanie »dlaczego? «. Nihilizm to sytuacja, w której »najwyższe wartości traca wartość «" [WM(a), 10]. Tak pojmowany nihilizm jest nieuniknioną konsekwencją ,śmierci Boga”. Po wtóre, nihilizm jest sposobem myślenia:

Najbardziej krańcową formą nihilizmu byłoby przeświadczenie: że każda wiara, każde wierzenie w prawdziwość czegoś są koniecznie fałszywe: ponieważ świata prawdziwego wcale nie ma. A więc: pozór perspektywiczny, którego pochodzenie leży w nas samych [...] - Jest to miarą siły, do jakiego stopnia możemy wyznać przed sobą pozorność, konieczność kłamstwa, nie zapadając się przez to. Dotyka nihilizm, jako zaprzeczenie istnienia jakiegoś świata prawdziwego, jakiegoś bytu, mógłby być boskim sposobem myślenia. [WM(a), s. 37-38]

Efektem myślenia nihilistycznego jest nie tylko zakwestionowanie powszechnie obowiązujących wartości, ale również najbardziej podstawowych prawd ${ }^{25}$. Błędem i naiwnościa jest, według Nietzschego, wiara nawet w to, że cokolwiek prawdziwego wiemy o zwyczajnym, otaczającym nas świecie, „o drzewach, barwach, śniegu i kwiatach". To, co nazywamy prawdą, to tylko ,interpretacje”, do których tak przywykliśmy, że bierzemy je za ,informacje o rzeczywistości” [PPI, 187,189]. Nie znamy „rzeczy w sobie”, a pojęcia tworzące ludzką wiedzę, to tylko metafory zbudowane na metaforach ${ }^{26}$.

${ }^{22}$ Cyt. za: M. Heidegger, Powiedzenie Nietzschego „Bóg umart”, tłum. J. Gierasymiuk, [w:] M. Heidegger, Drogi lasu, Warszawa 1997, s. 175.

${ }^{23}$ A.O. Lovejoy, Wielki łańcuch bytu, tłum. A. Przybysławski, Warszawa 1999, s. 378.

${ }^{24}$ Ibidem, s. 384.

25 Por. L. Kleszcz, Przełom hermeneutyczny w filozofii niemieckiej, s. 380-381.

${ }^{26} \mathrm{O}$ metaforyczności poznania pisali także R. Rorty (Filozofia jako nauka jako metafora $i$ jako polityka, [w:] Między pragmatyzmem a postmodenizmem, Toruń 1995, s. 17-23; Obiektywność, relatywizm, prawda, tłum. J. Margański, Warszawa 1999, s. 243-257), H. Arendt (Myślenie, tłum. H. Buczyńska-Garewicz, Warszawa 1991, s. 147-162) czy H. Blumenberg (Paradigmen zu einer Metaphorologie, Frankfurt am Main 1998). 
Wraz z wnikaniem w źródła teorii, filozofii, systemów wartości wzrasta świadomość ich braku znaczenia ${ }^{27}$. Szczytem (a może dnem) myślenia nihilistycznego jest uświadomienie sobie całkowitej przypadkowości i bezsensowności istnienia świata, życia i człowieka. Wszelka próba opisu świata nieuchronnie prowadzi ku jego „uczłowieczeniu”, a każda będzie interpretacją z ludzkiej (i w tym sensie subiektywnej) perspektywy, świat zaś leży „poza wszelkim naszym dobrem i złem”. Błędem jest przypisywanie światu jakiejś wartości. Równie chybione są wszelkie próby formułowania jakichś praw. Wprawdzie w przyrodzie występują pewne konieczności, lecz nie ma nikogo, kto miałby te prawa narzucać, podporządkowywać się im, czy też wyłamywać się spod ich działania. „Świat bez Boga” jest fascynującym w swoim przerażającym pięknie „potworem siły bez początku, bez końca”, podlegającym nieustannym przemianom, będącym dla Nietzschego tylko ,grą sił i fal"28. Jest to świat dionizyjski, sam siebie stwarzający, sam siebie niweczący, nie rządzony żadnymi prawami, nie zmierzający do żadnego celu ,jeśli celem nie jest szczęście w kole, bez woli, jeśli koło nie jest wolą obracania się na własnej, starej drodze wkoło siebie i tylko wkoło siebie" [WM(a), 448].

Istotą świata jest ,wola mocy”. To jedno z podstawowych pojęć filozofii Nietzschego, oznaczające nieredukowalną do niczego podstawę całej rzeczywistości, istotę zarówno świata, jak i ludzkiego życia: „Chcecie nazwy dla tego świata? Rozwiązania wszystkich jego zagadek? Światła także i dla was, wy najskrytsi, najsilniejsi, nieustraszeni, najmroczniejsi? - Ten świat jest wolą mocy - i niczym więcej? A i wy sami jesteście ową wolą mocy — i niczym więcej!" [WM(a), 448].

Konsekwencją myślenia nihilistycznego jest doświadczenie z całą mocą wspomnianego już „absolutyzmu rzeczywistości”"29. W obliczu świadomości znikomości ludzkiego losu, braku znaczenia, obojętności świata człowiek tworzy — jak powiada H. Blumenberg — różne strategie depotencjalizacji rzeczywistości. Jedną z nich jest „,snucie opowieści”, praca nad mitem.

Postawy wobec mitu maja trojaki charakter. Z jednej strony od ponad dwustu lat narasta postawa krytyczna, postawa redukcjonistyczna, polegajacca na wyjaśnianiu wszelkich zjawisk religijnych, mitów, symboli czy rytuałów poprzez pokazanie ich genezy czy funkcji i zredukowanie ich do zjawisk społecznych, politycznych, ekonomicznych czy psychologicznych. Odmienną postawę przyjmują myśliciele sytuujący się na biegunie przeciwnym, dowodzący specyfiki myślenia mitycznego, nieredukowalności zjawisk religijnych. Trzecia postawa mieści się pomiędzy tymi stanowiskami, a do tej grupy należą tacy myśliciele jak na przykład Leszek Kołakowski. Wskazują oni na nieredukowalny charakter myślenia mitycznego, które jest obecne nie tylko w życiu religijnym, lecz także w nauce, przekonaniach epistemologicznych, aksjologicznych. Elementami mitycznymi przeniknięte jest nasze życie codzienne, tkwią one w sztuce, literaturze czy obyczajach.

27 Por. G. Vattimo, Das Ende der Moderne, Stuttgart 1998, s. 26.

${ }^{28}$ L. Kleszcz, Przełom hermeneutyczny w filozofii niemieckiej, s. 394.

${ }^{29}$ H. Blumenberg rozwijał to pojęcie w kolejnych pracach: Die Genesis der kopernikanischen Welt (Frankfurt am Main 1965), Lebenszeit und Weltzeit (Frankfurt am Main 1986) i Praca nad mitem. Por. także F.J. Wetz, Hans Blumenberg zur Einführung, Hamburg 1993. 
Krytyka filozoficzna może próbować anulować tradycyjne pytania metafizyczne czy epistemologiczne, wskazując na ich „bezsensowność” czy „niepoprawność”, ale wcale w ten sposób nie usuwa potrzeby ich zadawania. Potrzeby metafizyczne wyrastające z pragnienia przeżywania świata doświadczanego jako sensownego, potrzeby wiary w trwałość wartości ludzkich czy pragnienia postrzegania świata jako pewnej sensownej całości, należą do nieeliminowalnych elementów natury ludzkiej. Leżące $\mathrm{u}$ ich podstaw ,pragnienie unieruchomienia czasu fizycznego przez nałożenie nań mitycznej formy czasu"30 może być zaspokojone tylko przez mit. Zwolennicy „trzeciej drogi” z jednej strony pokazują nierealizowalność projektu totalnej demitologizacji, z drugiej zaś pokazują cenę, jaką trzeba zapłacić za uczestnictwo w micie. Cenę polegającą na wyrzeczeniu się autonomii, w pewien sposób „zawieszeniu rozumu", zanegowaniu racji demistyfikatorów. Ta trzecia postawa wydaje się być najbliższa Nietzschemu, który próbował połączyć oba stanowiska. Z jednej strony był „mistrzem podejrzeń”, dokonującym wielostronnej dekonstrukcji kultury, z drugiej, chciał być twórca „nowej mitologii”, chciał dokonać „przewartościowania wartości”, wyznaczyć cel, który chaotyczny świat ponownie przemieni w „kosmos". Z punktu widzenia kultury taka postawa wydaje się najbardziej twórcza, a konflikt obu postaw ,dekonstruowania mitu” i ,kreowania mitu” jest konfliktem wartości ożywiającym kulturę, która wszak żyje pragnieniem syntezy ostatecznej a zarazem niemożnością jej dokonania. Tak postrzegany los kultury jest — jak zauważył Kołakowski - „epopeją wspaniałą przez swoją chwiejność”31. Przy bliższym przyjrzeniu ta „trzecia postawa” tė̇ wydaje się być uwikłana w ten nierozwiązywalny konflikt, gdyż ona sama również jest wyrazem pragnienia uwolnienia się spod władzy czasu poprzez przyjęcie „boskiego punktu widzenia”. W końcu, jak pisał Platon, takiej duszy, która z góry spogląda na cały świat, niczym wielkim nie wydaje się jedno ludzkie życie, nawet gdyby to było nasze życie. Jednak postawa filozoficzna, ów bezstronny, bezinteresowny obserwator postrzegany z perspektywy „sztuki podejrzeń” również okazuje się być uciekinierem ze świata przygodności, co gorsza, mało świadomym, bo zafascynowanym swoją ,wiedzą-władzą", pozornie sytuującą go poza czasem i przestrzenią.

Patrząc na filozofię Nietzschego z perspektywy „mitotwórczej”, widoczne stają się dwie kwestie. Po pierwsze, wyraźniejsze stają się związki Nietzschego z filozofią romantyczną. Mimo jego zaprzeczeń i uwag krytycznych, dostrzegalny jest wpływ nie tylko Hölderlina, ale także Novalisa, a zwłaszcza Schlegla. Ponadto, wbrew tradycyjnym podziałom jego twórczości na fazy, okresy, zwroty czy zerwania, odnoszę wrażenie, że wciąż porusza się on w tych samych ramach, które wyznaczają: diagnoza stanu kultury, a może nawet szerzej, ludzkiej kondycji, i krytyczna reakcja na tę diagnozę - niezgoda na „koegzystencję z pustką”. Diagnoza właściwie się nie zmienia i mówiąc najprościej, mówi ona o bezsensie ludzkiego istnienia. Najlepiej oddaje to słynny początek tekstu $O$ prawdzie $i$ kłamstwie w pozamoralnym sensie:

W pewnym odległym zakątku wszechświata wśród migotu niezliczonych systemów słonecznych była sobie raz gwiazda na której mądre zwierzęta wynalazły poznanie. Była to chwila największej py-

\footnotetext{
${ }^{30}$ L. Kołakowski, Obecność mitu, s. 10.

31 Ibidem, s. 152.
} 
chy i największego zakłamania w „dziejach świata” - ale też tylko chwila. Po paru tchnieniach natury gwiazda wystygła i mądre zwierzęta wymarły. [PPI, 183]

W kilkanaście lat później pisał: „A wiecie czym dla mnie jest »świat «? Mam go wam pokazać w moim lustrze? Ten świat to przerażająco ogromna siła, bez początku i bez końca, trwała, spiżowa miara siły, która się nie powiększa, ani nie pomniejsza, nie zużywa, lecz tylko przemienia..." [PP II, 339].

Nie tylko diagnoza, ale i reakcja pozostają w pewnym sensie takie same. We wspomnianych Narodzinach tragedii pisał, że ,życie potrzebuje ochronnej atmosfery utkanej z iluzji, snów, złudzeń”. Kilkanaście lat później pisze: „Wymyślić mit przyszłości! Żyć w nadziei! Błogosławione chwile! A potem znów zasłonić zasłonę i zwrócić myśli ku niewzruszonym, najbliższym celom!"32. Zmieniają się tylko formy „strategii przetrwania”, jakie tworzy Nietzsche. Rozpoczyna od Wagnerowskiego „mitu estetycznego”, który porzuca, by tworzyć „mit estetyzacji egzystencji”, uczynienia dzieła sztuki z własnego życia. Kolejnymi próbami nadania sensu ludzkiemu życiu była opowieść o nadczłowieku i rewitalizacja mitu wiecznego powrotu. Na marginesie mitotwórczej aktywności Nietzschego pojawia się pytanie, czy on sam wierzył w te mity. Czy można wierzyć w kłamstwa, które się samemu wymyśliło? Obawiam się, że jest to bardzo trudne, dlatego w twórczości Nietzschego obecny jest jeszcze jeden mit, mający bardziej osobisty charakter, to mit „mitotwórcy”, a więc kogoś, kto chroni się w swojej ,,jaskini”, by pisząc książki, tworzyć opowieści, które pozwolą mu wymknąć się spod władzy czasu.

\section{Bibliografia}

Arendt H., Myślenie, tłum. H. Buczyńska-Garewicz, Warszawa 1991.

Blumenberg H., Die Genesis der kopernikanischen Welt, Frankfurt am Main 1965.

Blumenberg H., Lebenszeit und Weltzeit, Frankfurt am Main 1986.

Blumenberg H., Paradigmen zu einer Metaphorologie, Frankfurt am Main 1998.

Blumenberg H., Praca nad mitem, tłum. K. Najdek, M. Herer, Z. Zwoliński, Warszawa 2009.

Eliade M., Aspekty mitu, tłum. P. Mrówczyński, Warszawa 1998.

Heidegger M., Powiedzenie Nietzschego „Bóg umart”, tłum. J. Gierasymiuk, [w:]

M. Heidegger, Drogi lasu, Warszawa 1997.

Heine H., Z dziejów religii i filozofii w Niemczech, tłum. T. Zatorski, Kraków 1997.

Kleist H. von, Listy, tłum. W. Markowska, Warszawa 1983.

Kleszcz L., Eliade - życie i mit, [w:] Studia mitoznawcze: filozoficzne i socjologiczne aspekty mitu, I. Błocian, E. Kwiatkowska (red.), Toruń 2010, s. 201-214.

Kleszcz L., Między miłościa a nienawiścia, czyli o dziwnej przyjaźni Nietzschego, [w:]

Nietzsche - muzyka i język, A. Gemel, J. Wroński (red.), Łódź 2016, s. 137-145.

Kleszcz L., Przełom hermeneutyczny w filozofii niemieckiej, Toruń 2007.

Kołakowski L., Mircea Eliade: religia jako paraliz czasu, [w:] M. Eliade, Traktat o historii religii, tłum. J. Wierusz Kowalski, Warszawa 1993.

${ }^{32}$ R. Safranski, Nietzsche, s. 341. 
Kołakowski L., Obecność mitu, Wrocław 1994.

Lovejoy A.O., Wielki łańcuch bytu, tłum. A. Przybysławski, Warszawa 1999.

Mieletinski E., Poetyka mitu, tłum. J. Dancygier, Warszawa 1981.

Namowicz T., Wstęp, [w:] Pisma teoretyczne niemieckich romantyków, T. Namowicz (red.), Wrocław-Warszawa-Kraków 2000.

Novalis, Uczniowie z Sais, tłum. J. Prokopiuk, Warszawa 1984.

Rorty R., Filozofia jako nauka jako metafora i jako polityka, [w:] Między pragmatyzmem a postmodenizmem, Torun 1995.

Rorty R., Obiektywność, relatywizm, prawda, tłum. J. Margański, Warszawa 1999.

Safranski R., Nietzsche. Biografia myśli, tłum. D. Stroińska, Warszawa 2003.

Schlegel F., Rozmowa o poezji, [w:] Pisma teoretyczne niemieckich roamntyków, T. Namowicz (red.), Wrocław-Warszawa-Kraków 2000.

Vattimo G., Das Ende der Moderne, Stuttgart 1998.

Wetz F.J., Hans Blumenberg zur Einführung, Hamburg 1993. 